\title{
УСКОРЕННАЯ ПОДГОТОВКА ЖИРОСОДЕРЖАЩИХ ПРОБ В АНАЛИЗЕ ДИОКСИНОВ И ПХБ МЕТОДОМ ХРОМАТО-МАСС-СПЕКТРОМЕТРИИ
}

\author{
Левашова Е.А., Зыкова Г.В., Финаков Г.Г. \\ ФГУП Научно-технический центр радиационно-химической безопасности \\ и гигиены ФМБА России, Москва, Россия \\ eabelinsk@yandex.ru
}

DOI: 10.26902/ASFE-11_119

Полихлорированные дибензо-п-диоксины (ПХДД), дибензофураны (ПХДФ), бифенилы (ПХБ) - одни из самых токсичных соединений Приложения С Стокгольмской конвенции о стойких органических загрязнителях (СО3) [1]. При поступлении в организм человека основная часть ПХДД/ПХДФ и ПХБ всасывается через желудочно-кишечный тракт (90\%), включается в биохимические процессы и аккумулируется преимущественно в жировой ткани и печени. Поскольку в подавляющем большинстве случаев степень кумуляции ПХДД/ПХДФ и ПХБ в биоте характеризует протяженность и направленность трофических цепей, то можно считать, что поступление этих веществ в организм человека в первую очередь связано с пищевыми продуктами [2].

Целью данной работы являлась разработка ускоренной пробоподготовки пищевых проб в анализе ПХДД/ПХДФ и ПХБ методом хромато-масс-спектрометрии (ГХ-МС).

Анализ супертоксикантов ПХДД/ПХДФ и ПХБ проводили в пробах пищевых продуктов $(\mathrm{n}=38)$ : мясо и молочные продукты. Для извлечения ПХДД, ПХДФ и ПХБ была разработана комплексная методика экстракции и очистки, позволяющая проводить подготовку проб как в «ручном режиме», так и в автоматической системе PLE Total-Rapid-Prep ${ }^{\mathrm{TM}}$ (FMS, Waltham, MA, USA). Измерение концентрации аналитов выполняли на магнитно-секторном массспектрометре высокого разрешения AutoSpec Premier фирмы Waters, США с газовым хроматографом 7890 фирмы Agilent Technologies, США. Для оценки полноты извлечения ПХДД/ПХДФ и ПХБ и контроля качества анализа использовали изотопно-меченые стандарты-имитаторы $\left({ }^{13} \mathrm{C}\right)$.

В работе приведен сравнительный анализ подготовки проб с использованием системы FMS (Waltham, MA, USA) со стандартной пробоподготовкой, обычно используемой в российских лабораториях - экстракцией в аппарате Сокслета, с использованием ультразвука и очисткой на хроматографических колонках. В результате сопоставления двух методов подготовки жиросодержащих проб для выполнения ГХ-МС анализа было выявлено ряд преимуществ автоматической системы пробоподготовки: сокращение трудозатрат и времени подготовки проб; снижение расхода используемых растворителей и хроматографических сорбентов; значительное упрощение работы с пробами, что привело к снижению возможных ошибок «человеческого фактора». Проведена оценка эффективности использования одноразовых хроматографических колонок большой ёмкости PCB-HCDS-ACD (Waltham, MA, USA), позволяющих выполнять очистку проб с высоким содержанием жира (5 г) без снижения извлечения целевых аналитов. Метод показал высокую степень извлечения ПХДД, ПХДФ и ПХБ (70-87\%).

Ускоренная подготовка проб с применением автоматизированной системы экстракции и очистки является перспективным методом в решении сложных задач ГХ-МС анализа высокотоксичных диоксинов и ПХБ в жиросодержащих матрицах.

\section{Сиисок литературы}

1. Stockholm Convention on persistent organic pollutants. // Stockholm. - 22 May 2001.

2. Майстренко, В.Н. Эколого-аналитический мониторинг органических загрязнителей / В.Н. Майстренко, Н.А. Клюев. - М.: БИНОМ. Лаборатория знаний, 2004. - 323 с. 